\title{
Maciej Duda
}

Uniwersytet Szczeciński

\section{Lektury maladyczne}

O książce Moniki Ładoń

Choroba jako literatura

\section{Abstract \\ Malady Readings. On Monica Ladoń's Book Choroba jako literatura}

This article reviews Choroba jako literatura [Illness as Literature] by Monika Ładoń. Ładon's essays establish malady studies in the field of Polish literature. She analyses fictions and autobiographies that cover the experience of disease. The scope of her research spans Polish and European prose of the twentieth and twenty-first centuries (including Thomas Mann, Franz Kafka, Maria Dąbrowska, Anna Kowalska, Jerzy Pilch, Krystyna Kofta, and Grażyna Jagielska). Ładon's theoretical perspectives are set by Emil Cioran, Hans-Georg Gadamer, Catherine Malabou, and the duo of Julia Kristeva and Jean Vanier.

Słowa kluczowe: narracje maladyczne, metafora, somatopoetyka, Monika Ładoń

Keywords: malady narratives, metaphor, somatic poetics, Monika Ładoń

Tytuł Choroba jako literatura to wyraźny trop interpretacyjny. Pobrzmiewa w nim temat klasycznego już eseju Susan Sontag. Jego krytyczna lektura rozpoczyna maladyczne rozważania Ładoń. Sceptycyzm badaczki nie odbiega od wcześniejszych ujęć podważających założenia Sontag. Ładoń raczej je sprawozdaje, niż czyta z ukosa. Toteż pierwsze strony jej książki ponownie, za innymi badaczami, oświetlają główny paradoks eseju amerykańskiej intelektualistki, która walcząc z metaforami, sama z nich korzystała, a atakując interpretację jako formę rozumienia sztuki, zarazem nieustannie interpretowa- 
ła. Według autorki $W$ Ameryce metafora miała upraszczać lub redukować opis i rozumienie choroby. Jej polemiści sądzili raczej, że tak radykalny pogląd osłabia lub całkowicie wyklucza możliwość zrozumienia choroby jako stanu, etapu życia. Ładoń twierdzi z kolei, że „,bagaż rzekomo szkodliwych metafor jest niedającym się usunąć elementem maladycznych narracji”". Jednocześnie jednak nie odrzuca tez Sontag, a - jak pisze - czytając ją, stawia jedynie znaki zapytania i osłabia wywrotowość jej tekstu.

Jak słusznie zauważa, esej Choroba jako metafora nie powstawał ad hoc. Nie jest zapisem choroby, pozbawiony został również autobiograficznych odniesień. Literatura, której przyglądać będzie się Ładoń, jest wobec niego biegunowo odmienna. Zdaniem badaczki ,ze środka choroby nie mogłaby wydostać się narracja tego rodzaju" (s. 16), podobna do rozważań Sontag narracja, która wypiera chorobę, nie nadaje jej znaczenia, nie rozbudza wyobraźni odbiorcy - a właśnie takie opowieści interesować będą Ładoń.

Jej badania wynikać mają z podstawowego dylematu: czy posługując się metaforami, zbliżamy się czy oddalamy od opisu/doznania choroby. W ten sposób Ładoń odrzuca antyhermeneutyczny nakaz Sontag, który pozostawił nam jedynie możliwość opisu choroby jako faktu, czyli choroby jako choroby. Jego respektowanie skazywałoby chorujących na medykalizację ich stanu, czyli na pozaliterackie rozumienie własnej kondycji. Odbierałoby możliwość dyskursywnego opisu choroby, a przecież to właśnie taki opis zdaje się patronować literaturze XX i XXI wieku, którą czyta Ładoń. Posłuszeństwo wobec postulatu Sontag oznaczałoby również odrzucenie bliskiego badaczce łączenia metafory z doświadczeniem (za Lakoffem i Johnsonem), co prowadzić ma do aktywności, do możliwości działania, które nadaje porządek lub strukturę lękowym stanom chorobowym.

Inną formą obecności eseju Sontag w badaniach Ładoń jest jego odbicie w strukturze opisywanej książki. Jak pisze autorka:

[...] trzy rozdziały odtwarzają jej tok myślenia ufundowany na podobieństwach i różnicach między gruźlicą, nowotworem i zawałem. Podaję w nich w wątpliwość kilka jej tez: po pierwsze, tezę o wyczerpaniu się romantycznej figury gruźlika, po drugie, przekonanie o niepodatności raka na estetyzację, po trzecie, stwierdzenie, że zawał jest tylko „awarią mechaniczną”, niemającą kształtu metaforycznego (s. 24).

Metafora zostaje zastąpiona literaturą, jednak zdefiniowanie dyskursu maladycznego jest problematyczne. Badaczka rozumie go dwojako, diachronicznie i synchronicznie. Diachronicznie rozpatruje go na podstawie własnych kilkuletnich zainteresowań badawczych. Jak twierdzi, początek jej badań zbiegał

${ }^{1}$ M. Ładoń, Choroba jako literatura. Studia maladyczne, Katowice 2019, s. 14. Dalsze cytaty z tej książki identyfikuję bezpośrednio w tekście. 
się z sytuacją, w której dociekania nad chorobą wymuszały pytanie o to, dlaczego choroba nie została wyróżniona i opisana, tak jak starość i śmierć. Z kolei w momencie pisania wstępu do recenzowanej książki problematyka chorobowa doczekała się swoistego zwrotu maladycznego. Ostatnie sformułowanie Ładoń umieściła w cudzysłowie. Metaforyzując ów stan, pisze o „wybuchu szczególnego rodzaju epidemii” (s. 29). W taki sposób dystansuje się wobec samej praktyki ogłaszania kolejnej interpretacyjnej wolty. Ten badawczy dystans łączy się z synchronicznym obrazowaniem maladycznego dyskursu, z niesystemowością czy brakiem uporządkowania badań, które równolegle prowadzone są w literaturoznawstwie, językoznawstwie, kulturoznawstwie, socjologii medycyny, bioetyce czy filozofii.

W tym miejscu należy jednak zapytać, jak sama autorka definiuje pojęcie dyskursu maladycznego. Za Kazimierzem Szewczykiem, opisującym filozoficzne podstawy bioetyki, odwołuje się ona do skupienia na maladycznych ${ }^{2}$ i tanatycznych metaforach, które dominują w medycznych opowieściach snutych przez pacjentów narratywizujących swój los przed samymi sobą lub innymi. Z kolei sam dyskurs, a raczej spore badawcze zainteresowanie tematem choroby, oznaczony został jako ,niezwykle gościnny, ale i fragmentaryczny, niekompletny" (s. 29), wielokierunkowy i niesystemowy. Ta charakterystyka po wielekroć odbije się w książce Ładoń. Przyjdzie mi do niej wrócić w dalszej części tego omówienia.

Wybór i opis maladycznych metanarracji określony został mianem impulsów. Najważniejszy z nich pochodzi z narracji Krystyny Pietrych piszącej o empatycznych przestrzeniach lektur. Ładoń przywołała kategorie współbycia z autorami. Czytanie ma być praktyką budowania wspólnoty. Jako takie pozbawione zostało „mocnych reguł czytania” (s. 30). Nie oznacza to jednak, że proces konceptualizacji lektur odbywa się bez metodologicznego odniesienia. Reprezentacje doświadczania bólu i cierpienia związane ze stanami chorobowymi podzielić można wedle trzech istotnych kategorii. Wśród nich znajdą się odsłony somatyczne, empatyczne oraz prezentacje podporządkowane lekturom akcentującym odniesienia etyczne. Obszerne bibliografie wskazanych kierunków interpretacji umieszczone zostały w stosownych przypisach. Metarefleksja plasuje pisanie Ładoń w przestrzeni literaturoznawczej lub interdyscyplinarnej. Ta ostatnia obejmować może „spotkania między literaturą a medycyną" (s. 32). Wymienione kierunki mają ujawniać klasycznie rozumiane kulturoznawcze interpretacje narracji chorobowych. Obok nich autorka umieściła także nowe praktyki lekturowe obejmujące deskrypcyjne przedstawienia patografii (badania Mateusza Szuberta ${ }^{3}$ ) oraz autopatografii

2 Maladyczny, od łac. malus - zły, nieszczęśliwy, równoległa forma morbudyczny pochodzi od łac. morbus - choroba.

${ }^{3}$ M. Szubert, Dyskurs maladyczny pólpauza perspektywy badawcze [w:] Fragmenty dyskursu maladycznego, red. M. Ganczar, I. Gielata, M. Ładoń, Gdańsk 2019. 
(badania Iwony Boruszkowskiej ${ }^{4}$ ) i kancerografii (termin Małgorzaty Okupnik $^{5}$ ). W akapitach wprowadzających do swojego zbioru sprawozdała również napięcia wynikające z zestawienia przez Boruszkowską kategorii defektów i afektów oraz użycia przez nią terminów: podmiot defektywny, doświadczenie defektywne, narracje defektywne oraz z wąskiego użycia przez Okupnik terminu utrata (tylko w kontekście utraty zdrowia). Jednocześnie wstępne rozważania dotyczące choroby jako literatury nie przynoszą samodzielnych propozycji analitycznych czy opisowych, a w umieszczonych dalej szkicach interpretacyjnych nie odnajdziemy wyraźnych śladów użycia wyszczególnionych wyżej terminów. Ładoń przekonuje nas, nie bez racji, że wskazane kierunki i terminy, więc sposoby badań dyskursu chorobowego, odnoszą się do tych samych pytań i problemów. Ich podstawą jest aporetyczna wyrażalność/ niewyrażalność doświadczanej choroby, związanych z nią cierpień i bólu. Chęć zrozumienia i współbycia z chorującym zrównana zostaje z możliwością jego (auto)upodmiotowienia, $\mathrm{z}$ odejściem od kartezjańskiego dualizmu ciała i ducha oraz ze zniesieniem opozycji zdrowia i choroby. W tych przesunięciach Ładoń dostrzega możliwość „redefiniowania tożsamości chorego” (s. 36).

Cytaty ze wstępnych rozważań badaczki mają obrazować przygodność i nieścisłość jej języka. Zadanie, jakie przed sobą postawiła - zrozumienie doświadczeń chorujących podmiotów, albo inaczej: podmiotów żyjących chorobą lub podmiotów żyjących w chorobie - wiąże się z unikaniem domykania, uspójnienia czy ujednoznaczniania tego, co właśnie metaforyczne. Oznacza to również, że przygodność prowadzonych przez nią badań wiąże się z brakiem konkluzji, a sam język jest niekończącym się ciągiem wyjaśniających i jednocześnie komplikujących sensy metafor. Tak mogłaby wyglądać definicja literatury konstruowana przez autorkę opisywanej książki. Nieostra i migotliwa.

Rozważania wstępne obejmują również prezentację innych patronów badań Ładoń. Poza Susan Sontag badaczka inspiruje się zapisami Emila Ciorana, Hansa-Georga Gadamera, Catherine Malabou oraz duetu Julii Kristevej i Jeana Vaniera. Wypisy z Ciorana przynoszą tezę o wzmożonej cielesności stanu chorobowego i o wyostrzonej świadomości posiadania ciała. W rozumieniu rumuńskiego filozofa choroba, więc niedogodność, niedyspozycja fizyczna, staje się pośredniczką między dychotomicznie zestawianym umysłem i ciałem. Dzięki fizycznemu cierpieniu odzyskujemy swoje ciało, zauważamy je i zaczynamy odczuwać. Istniejemy, dysponując organizmem i świadomością. Cierpienie nie nabiera tu wartości etycznej, uszlachetniającej, raczej sprowadza na nas refleksję i pozwala nam dostrzegać to, czego nie widzieliśmy w stanie zdrowia. Choroba, w przeciwieństwie do zdrowia, jest więc

${ }^{4}$ I. Boruszkowska, Defekty. Literackie auto/pato/grafie: szkice, Kraków 2016.

${ }_{5}^{5}$ M. Okupnik, $W$ niewoli ciała. Doświadczenie utraty zdrowia i jego reprezentacje, Kraków 2018. 
pełnym bytem. Dodatkowo zbliża nas do istoty śmierci. To zyski z choroby, które za Cioranem proklamuje Ładon. W tym rozumieniu narracja chorego egoistyczna opowieść o własnych dolegliwościach - zawiera również sekretne pragnienie, by wszyscy byli chorzy. To odsłania paradoks myśli Ciorana. Choroba jednocześnie jest dla niego stanem niosącym wskazane zyski oraz czasem, gdy głos chorującego ujawnia gniew i żal ${ }^{6}$.

Podobne sensy płyną z lektury Gadamera, dla którego stan zdrowia również jest czasem samozapominania, przegapienia, braku skupienia. Nie wymaga od nas uwagi, jest przezroczysty, nie jest dla nas zadaniem, z którym musimy się uporać. Zdrowie jest stanem, którego nie rozumiemy bez doświadczenia choroby. Brak choroby staje się wyznacznikiem zdrowia. Przy czym sam stan chorobowy nie zostaje u Gadamera nadwartościowany tak jak u Ciorana. Dla niemieckiego humanisty silniejsza jest harmonia widoczna (zdrowie) niż niewidoczna (choroba) ${ }^{7}$.

Inaczej opozycję zdrowia i choroby zaciera Malabou, dla której oba stany są drogą, ilustrują transformację, stawanie się kimś innym. Używane przez nią pojęcie destrukcyjnej plastyczności pozwala ilustrować tożsamościową zmianę, choćby w przypadku osób chorujących na alzheimera. W tym ujęciu choroba jest stanem, momentem, siłą, które umożliwiają otwarcie, nowy początek. Taką refleksję przynoszą obserwacje chorób neurologicznych. Według Malabou można je opisać jako zerwanie z dotychczasową podmiotowością, czego nie zrównuje się ze śmiercią podmiotu, lecz z jego destrukcyjnym przekształceniem. W przeciwieństwie do klasycznej psychoanalizy czy neurobiologii, które przypatrują się możliwości pozostania sobą/tym samym w zmianie, francuska filozofka skupia się na przekształceniu osobowości, którą nazywa absolutną egzystencjalną improwizacją ${ }^{8}$.

Obok otwierającej koncepcji Malabou wybrzmiewa głos Kristevej dyskutującej z Vanierem. Lektura listów francuskiej intelektualistki, matki mężczyzny z niepełnosprawnością, do założyciela wspólnoty, w której osoby chore i zdrowe razem pracują i wzajemnie się sobą opiekują, pokazuje nam chorobę z perspektywy współbycia, współtowarzyszenia. Humanizm postulowany przez Kristevą opiera się na pojęciu troski wobec tych, którzy są zależni od innych. Badaczka przygląda się pojęciom słabości i kruchości. Oba traktu-

${ }^{6}$ Zob. E. Cioran, Ćwiartowanie, przeł. M. Falski, Warszawa 2004; idem, Na szczytach rozpaczy, przeł. I. Kania, Kraków 1992; idem, Sylogizmy goryczy, przeł. I. Kania, Warszawa 2009; idem, Upadek w czas, przeł. I. Kania, Warszawa 2008; idem, Zeszyty 1957-1972, przeł. I. Kania, Warszawa 2016; idem, Zmierzch myśli, przeł. A. Dwulit, Warszawa 2004.

7 Zob. H.-G. Gadamer, O skrytości zdrowia, przeł. A. Przyłębski, Poznań 2011; idem, Prawda i metoda. Zarys hermeneutyki filozoficznej, przeł. B. Baran, Kraków 1993.

${ }^{8}$ Zob. C. Malabou, Ontologia przypadłości. Esej o plastyczności destrukcyjnej, przeł. P. Skalski, Warszawa 2017. 
je jako uspójniające, budujące wspólnotę, a nie ujawniające różnice między zdrowymi i chorymi (w tym wypadku niepełnosprawnymi). Słabość nie jest elementem wyróżniającym czy odróżniającym, lecz upodabniającym?

Filozoficzne wypisy skolekcjonowane przez Ładoń odsyłają nas do głównego celu jej pracy, do osłabienia, a nawet przekroczenia opozycji między zdrowiem a chorobą. Badaczka widzi w nich wzajemne, uzupełniające się wartości czy stany. Taka konceptualizacja pozwala jej wyjść poza dyskurs kliniczny, jednocześnie nie odrzucając go w pełni. To niezaprzeczona wartość najnowszych tak prowadzonych studiów maladycznych, które pod ręką Ładoń fragmentarycznie przecinają się ze studiami o niepełnosprawnościach. W tym momencie należy jednak przyjrzeć się temu, jak wstępne rozważania badaczki rezonują w poszczególnych, składających się na książkę, interpretacjach literatury.

Zebrane tu szkice podzielone zostały na cztery główne kategorie. Każda z nich zawiera prace, które studiować możemy jako osobne - że użyję tego, zdaje się niemaladycznego określenia - przypadki. I tak, najpierw trafimy do sali czy na półkę z opisami i wyznaniami gruźliczymi, następnie do oddziału nowotworowego, by na końcu odwiedzić tzw. sercowców. Skromniejsza część książki obejmuje prezentację pism (literatury), których badaczka nie zaklasyfikowała jednoznacznie. Zawarte w niej epikryzy nie zawierają diagnozy, a co za tym idzie - pozbawione zostały zaleceń wskazujących tzw. dalsze postępowanie. Rozpoczynając ostatnią część badań, Ładoń postawiła pytanie Zdrowie czy choroba? - i nie udzieliła żadnej odpowiedzi. W ten sposób wypełniła stawiany sobie cel. Ale po kolei.

Tuberkuloza odsyła nas do sanatoriów i kanonicznych modernistycznych odsłon choroby w Mannowskim i Kafkowskim wydaniu. Zestawienie narracji beletrystycznej (Mann) i autobiograficznej (Kafka) wydobywa napięcia związane z konkretną cechą choroby czy zachowania chorujących. Tu Ładoń idzie za Sontag, która orzekła: „,[u]ważano - i uważa się nadal - że gruźlica wywołuje okresy [...] zwiększonego apetytu"10. Zestawienie dwóch klasyków ujawnia podwójność opisywanego stanu chorobowego - jednoczesne zjadanie (posiłków) i bycie zjadanym (przez chorobę). Wskazane aktywności dookreślają metafory związane ze zmysłem słuchu. Desperackie konsumowanie jest chęcią zagłuszenia choroby, dźwięki trawienia symulują zdolność życia, aktywność ciała. Z czasem zastąpi je kaszel, charkot, czyli - według Ładoń melodia zamierającego ciała. Konsumowanie ciała przez chorobę obrazuje również opis Dziennika z łoża śmierci Williama Soutara. Ten ostatni zestawiony został z kolei z postacią Lucjana Salisa, bohatera Wspólnego pokoju Zbi-

9 J. Kristeva, J. Vanier, (Bez)sens słabości. Dialog wiary z niewiara o wykluczeniu, przeł. K. Wierzchosławska, P. Wierzchosławski, Poznań 2012.

10 S. Sontag, Choroba jako metafora. AIDS i jego metafory, przeł. J. Anders, Kraków 2016, s. 14. 
gniewa Uniłowskiego. Ponownie - biograficzny i beletrystyczny obraz dwóch mężczyzn ukazać ma kontrast wynikający z ich chorobowych doświadczeń. Po stronie Soutara pojawi się afirmacja twórczej aktywności do ostatnich dni, zapisywanie myśli w dzienniku trzymanym pod poduszką. Salisa cechować będzie letarg, poczucie niemożności i nuda. Różnice w postawach chorujących wiązać można $\mathrm{z}$ ich różnymi dyspozycjami charakterologicznymi, doświadczeniami życiowymi oraz warunkami socjalnymi, w których się znajdowali. Nie te wątki wydają się jednak najważniejsze w gruźliczej odysei. Punktem krańcowym jest interpretacja Hotelu de Dream Edmunda White'a. Ładoń skupiła się tu na lekturze obejmującej dyskusję z Sontag. Katowicka badaczka pokazuje trwanie i funkcjonalizację ,gruźliczej poetyki” (s. 87), pomimo jej zakwestionowania przez amerykańską intelektualistkę. To wszystko, co połączone zostało z chorobowymi fantazjami, z mitologią dotyczącą tuberkulozy, pojawi się w powieści jako kostium narracji o HIV i AIDS. „Ekwiwalent” tak o doświadczeniu chorobowym bohatera Hotelu de Dream i doświadczeniu życiowym Edmunda White'a pisze Ładoń (s. 96). W tym wydaniu AIDS staje się chorobą wybrańców. W tym momencie ta maladyczna interpretacja robi się nader interesująca. Niestety, jest to też moment, w którym Ładoń kończy. White'owska gruźlica maskować może prostytucję, syfilis i w końcu HIV oraz AIDS. Takie zestawienie wpierać musi mitologizujące ujęcie ostatniej choroby. W tym pomaga badaczce kulturowa analiza Moniki Sznajderman, zestawiającej dżumę, cholerę i AIDS ${ }^{11}$. Przypomnieć należy jednak, że książka Sznajderman ukazała się ćwierć wieku przed badaniami Ładoń. Z kolei książka White'a została po raz pierwszy opublikowana w roku 2007, a jej polskie wydanie - w 2012. W ciągu tych lat zmienił się stosunek do HIV. Już pod koniec ósmej dekady XX wieku Sontag pisała: ,[n]awet choroba najbardziej przepełniona znaczeniem może stać się jedynie chorobą [...]. Tak też musi stać się z AIDS, kiedy choroba zostanie lepiej zrozumiana"12. I tak też stało się na długo przed opublikowaniem Choroby jako literatury. Ładoń ma dostęp do narracji, które nazwałbym pośrednimi, do tych, które tematyzują, ale nie mitologizują życia z wirusem HIV. Mam tu na myśli, by pozostać przy najpopularniejszych przykładach, zbiór opowiadań Trafieni, a także książki Maćka Millera lub Marcina Szczygielskiego ${ }^{13}$. Ciekawsze pozostaje jednak to, jak wybrzmiałby Hotel de Dream w kontekście życiowych doświadczeń jego autora, gdyby zestawiać go z książką Jakuba Janiszewskiego Kto w Polsce ma $H I V ?{ }^{14}$ oraz z dostępną od kilku lat wiedzą, która podważa mitologiczny status

${ }^{11}$ M. Sznajderman, Zaraza. Mitologia dżumy, cholery i AIDS, Warszawa 1994.

12 S. Sontag, op.cit., s. 170.

${ }_{13}$ Zob. Trafieni. 7 opowiadań o AIDS, Warszawa 2005; M. Miller, Pozytywni, Kraków 2005; M. Szczygielski, Berek, Michałów-Grabina 2007.

${ }_{14}$ Zob. J. Janiszewski, Kto w Polsce ma HIV? Epidemia i jej mistyfikacje, Warszawa 2013. 
$\mathrm{HIV}^{15}$. W tym miejscu idę w sukurs Sontag. Nie mam jednak zamiaru rewidować interpretacji Ładoń, ale raczej wskazać ścieżki, które prowadzą w to samo miejsce, do którego podąża badaczka. Przypomnę - chce ona wykroczyć poza lub zamazać opozycję zdrowia i choroby. Wydaje mi się, że gdyby nie porzuciła sygnalizowanych tropów, gdyby odczytała je w kontekście współczesnych badań, dotarłaby do upragnionego paradoksu już w tym miejscu. Połączyłaby w jedno zdrowie (stan zaleczenia, niewykrywalność) i chorobę (nieusuwalność wirusa). Co więcej, wydaje się, że byłoby to miejsce puste, jeszcze nieoznaczone artystycznymi narracjami. Nierozpoznane, więc tylko wyobrażone, a zatem pozbawione metafor. Równocześnie jednak, jako takie, samo staje się ono metaforyczne, jest literaturą wyobrażoną albo stanem/życiem podobnym do tego, które opisywał wspomniany wyżej Cioran. Niestety, odrzucenie tych tropów w prosty sposób zapętliło znaczenie HIV, AIDS i tuberkulozy. Z kolei ich podjęcie niekoniecznie oznaczałoby zgodę czy podległość hipotezom Sontag.

Maladyczne studia nowotworowe i zawałowe nie pozostawiają pustych miejsc. Zapiski chorobowe Marii Pawlikowskiej-Jasnorzewskiej, dzienniki Marii Dąbrowskiej, narracja Krystyny Kofty oraz zawałowe eseje Jana Kotta, szpitalne zapiski i listy Mirona Białoszewskiego - podobnie jak w zestawieniu Manna i Kafki - obrazują różne formy (mniej lub bardziej autobiograficzne) pisania o sobie i swoich doświadczeniach życia w chorobie. Dodatkowo narracja Anny Kowalskiej oświetlona zostaje dziennikiem Dąbrowskiej oraz jej korespondencją z Jerzym Stempowskim. Interpretacje dokumentów Dąbrowskiej wypełniają wspomnianą już, kluczową część książki Ładoń, zatytułowaną Zdrowie czy choroba? Dopełnia ją lektura dzienników Jerzego Pilcha oraz Miłości z kamienia Grażyny Jagielskiej.

Niniejsze omówienie nie wiąże wskazywanych interpretacji. Mimo wspólnego maladycznego mianownika ani kolejne interpretacje, ani ich recenzyjna enumeracja nie kumulują znaczeń. Dla przykładu, szkice dotyczące chorobowych fragmentów tekstów Kowalskiej i Dąbrowskiej są w jej lekturze właściwie rozłączne, przecięte opisami innych narracji, zgodnie z przyjętym porządkiem chorobowym. Kowalska leży na onkologii, wśród innych chorych. Dąbrowska znajduje się poza klasyfikacją chorób. Między nimi mieszczą się zawałowcy. Narracje obu pisarek spajają jedynie cytaty z badań Moniki Świerkosz ${ }^{16}$ lub przypisy. Taki układ podkreślać może samotność wpisaną w dzienniki Kowalskiej. Zakładam jednak, że studia maladyczne tę samotność

15 Tutaj odwołuję się do tekstów z dziedziny medycyny oraz publicystki popularyzującej wiedzę medyczną ze wskazanego zakresu.

16 Zob. M. Świerkosz, Atena i Arachne? Maria Dabrowska i Anna Kowalska we wzajemnej lekturze dzienników [w:] Czytanie. Kobieta, biblioteka, lektura, red. A. Zawiszewska, A. Galant, Szczecin 2015, s. 331-347. 
powinny wieloaspektowo tematyzować, zarówno w świetle relacji ${ }^{17}$ pozostawionych przez najbliższych, w tym przypadku przez Dąbrowską, jak i w kontekście interpretacji zapisanych snów, które przytacza Ładon. W tym przypadku sen Kowalskiej otrzymuje jednorodną Bachelardowską interpretację (woda - śmierć, zob. s. 124), a wydaje się, że przytoczona dalej przez badaczkę fantazja na temat podwojonej postaci Matki-Maryjki (zob. s. 124) przywołuje wątek pragnienia opieki, matczyności, wód płodowych, więc odnosić się może do narodzin, do prób zaprzeczenia śmierci. Moją glosę uprawomocnić może kolejny przytoczony przez Ładoń cytat z dzienników Kowalskiej, ten, w którym diarystka pisze o własnym zmartwychwstaniu (zob. s. 125). To oczywiście interpretacyjny szczegół, którego nie rozwiązuje teoria marzeń sennych, podaję go jednak jako taką egzemplifikację, która paradoksalnie odrzuca to, czego badaczka szuka w studiach maladycznych: wieloznaczność, niewypowiedzianą wprost kontekstowość.

Podobnie czytam np. zawałowe teksty Mirona Białoszewskiego. Chciałbym zapytać o to, czego tam nie ma. A nie ma w nich ciała. Zastępują je rurki, szpitalna aparatura. Znika somatyczność, tak sprawnie odnajdowana w tekstach pisanych przez kobiety. Serce, również w zapiskach Kotta, staje się symboliczne, wieloznaczne, przez co traci podstawową cielesno-fizjologiczną konotację. Te różnice są interesujące i z pewnością nie dają prostych odpowiedzi. Problematyczny wydaje się tu jednak brak badawczego pytania o nie. Jakikolwiek labirynt by ono otwierało, jest to labirynt maladyczny. $L i$ sty do Eumenid, które czyta Ładoń, zostały włączone także w Tajny dziennik Białoszewskiego. Ta wspólna lektura przynosi cielesne i seksualne konotacje, które nie wybrzmiewają w Chorobie jako literaturze. Wystarczy zestawić fizjologiczne opisy z życia szpitalnego z dziennikowymi opisami podróży do USA. Pisząc o tych pierwszych, Ładoń wspomina o „intymnych strategiach” (s. 169) oswajających realność oddziału, te drugie odsłaniają to, co najintymniejsze poza życiem w ,sercowisku”. Jednocześnie, za Małgorzatą Czermińską, badaczka dostrzega inną zbieżność w twórczości poety. Czytając jego zawałowe zapiski, stawia hipotezę na temat związków między opowieściami o powstaniu warszawskim i pobycie w szpitalu. Te dwa wydarzenia mają być przełomowe w biografii autora. W tym miejscu zabrakło odniesienia do pracy Joanny Niżyńskiej, która wybraną twórczość Białoszewskiego interpretowała w kontekście studiów nad traumą oraz studiów queerowych. Autorka

${ }^{17}$ Tę kwestię najciekawiej zilustrować mogłaby zawarta w recenzowanym tomie interpretacja książki Grażyny Jagielskiej Miłość z kamienia. Chorowanie za kogoś, kontenerowanie (termin Wilfreda Biona) stanów emocjonalnych męża ciekawie dopełniłoby rozważania na temat tekstów-relacji Dąbrowskiej, Kowalskiej i Stempowskiego. Wydaje się jednak, że badawcza motywacja objęła w tym przypadku przede wszystkim prezentację tekstu na temat choroby psychiki, nie ciała, w ten sposób paradoksalnie dopełniając zakres chorobowy, nie relacyjny. 
Królestwa małoznaczącości ${ }^{18}$ postawiła wówczas ciekawą tezę, wedle której całą twórczość autora Pamiętnika z powstania warszawskiego uspójnić można lekturą traumatologiczną. W tej koncepcji jego kolejnych dzieł nie rejestrujemy jako osobnych (tematycznie i formalnie; osobno poezja, pamiętnik i małe prozy) fenomenów, lecz jako kolejne odbicia traumatycznych, wypieranych przeżyć. W ten sposób narracja zawałowa przesuwa się w stronę tego, o co pyta Ładoń - nierozstrzygnięcia zdrowia/choroby.

Zadaniem powyższych uwag jest splątanie lektur, które skolekcjonowała badaczka. Chcę pokazać to, co mógłby odsłonić inny układ szkiców oraz pytania o to, czego nie odsłaniają poszczególne maladyczne zapisy. To zapowiada zaproponowana przez Ładoń lektura tekstów podmiotu. Impuls badawczy, o którym pisze autorka (zob. s. 41), owocuje zestawieniem teorii, które rozbudzają apetyt czytelnika. Niestety, skolekcjonowane interpretacje istnieją tu jakby w oderwaniu od siebie i od błyskotliwego wstępu, osobno. Być może to tylko kwestia redakcyjnego braku połączeń, podsumowań, konstatacji, które jednocześnie odnosiłyby się do wstępu oraz kolejnych lekturowych prezentacji. Badaczka nie porządkuje kolejnych tez. Ich układ prezentuje spis treści, a kolejne teksty pozostają $\mathrm{w}$ osobnych orbitach chorób, ale też form i kultur czy obiegów literackich. Ta wielość potrzebuje tematyzacji, czegoś, co anglosaskie poradniki pisania akademickiego nazywają signposting, czyli przypominaniem czytelnikowi/czytelniczce, w którym miejscu się znajduje i w jakim kierunku prowadzi go tekst. Powyższe wiąże się też z krótkimi, zawartymi wewnątrz rozdziałów podsumowaniami, wnioskami, które wprowadzają lekturowy porządek i zawiązują relacje między osobnymi szkicami. Ów porządek, o który się upominam, przyniósłby również informacje na temat autorskich wyborów kształtujących przedmiotowe pole badań. Czytelnik nie wie, w jaki sposób ono powstało, co zostało na jego marginesie i dlaczego.

Pisząc te słowa, zdaję sobie sprawę z faktu, że krytyka kontekstowa - tak ją nazwę na potrzeby tego omówienia - wydaje się najłatwiejszym odruchem aksjologii literatury/badań. Pytania o to, co jest, dlaczego jest, oraz o to, czego nie ma i dlaczego nie ma, wydają się często dyskusją zastępczą, marginalną. Jednak w tym wypadku Ładoń nie tematyzuje swoich wyborów, nie oznacza również miejsca, z którego pisze. Po bogatym i zapowiadającym ciekawe interpretacje wstępie otrzymujemy pozbawiony metanarracji wybór interpretacji. W ten sposób kształt kolekcji zaproponowanej przez badaczkę przypominać może wyznanie interpretowanego przez nią Pilcha:

Nie sporządzam bibliografii tematu choroba, nie gromadzę książek na ten temat, nie porządkuję biblioteki pod tym kątem [...], wszystko dzieje się samo. Zmienił

18 J. Niżyńska, Królestwo małoznaczacości. Miron Białoszewski a trauma, codzienność i queer, przeł. A. Pokojska, Kraków 2018. 
się punkt widzenia [...], nowa i wszechogarniająca wrażliwość się objawiła - bibliografia sporządza się z automatu, książki lgną do siebie ${ }^{19}$.

To, co uchodzi w beletrystyce, eseistyce czy w dokumencie osobistym, nie znajduje usprawiedliwienia $\mathrm{w}$ humanistyce akademickiej. $\mathrm{Z}$ tego powodu podjąłem się omówienia wyszczególnionych braków, które w jakiś sposób naznaczają olbrzymi wkład pracy Moniki Ładoń, będący podstawą opisywanych studiów maladycznych.

\section{Bibliografia}

Boruszkowska I., Defekty. Literackie auto/pato/grafie - szkice, Kraków 2016.

Cioran E., Ćwiartowanie, przeł. M. Falski, Warszawa 2004.

Cioran E., Na szczytach rozpaczy, przeł. I. Kania, Kraków 1992.

Cioran E., Sylogizmy goryczy, przeł. I. Kania, Warszawa 2009.

Cioran E., Upadek w czas, przeł. I. Kania, Warszawa 2008.

Cioran E., Zeszyty 1957-1972, przeł. I. Kania, Warszawa 2016.

Cioran E., Zmierzch myśli, przeł. A. Dwulit, Warszawa 2004.

Gadamer H.-G., O skrytości zdrowia, przeł. A. Przyłębski, Poznań 2011.

Gadamer H.-G., Prawda i metoda. Zarys hermeneutyki filozoficznej, przeł. B. Baran, Kraków 1993.

Janiszewski J., Kto w Polsce ma HIV? Epidemia i jej mistyfikacje, Warszawa 2013.

Kristeva J., Vanier J., (Bez)sens słabości. Dialog wiary z niewiara o wykluczeniu, przeł. K. Wierzchosławska, P. Wierzchosławski, Poznań 2012.

Malabou C., Ontologia przypadłości. Esej o plastyczności destrukcyjnej, przeł. P. Skalski, Warszawa 2017.

Niżyńska J., Królestwo małoznaczacości. Miron Białoszewski a trauma, codzienność i queer, przeł. A. Pokojska, Kraków 2018.

Okupnik M., W niewoli ciała. Doświadczenie utraty zdrowia i jego reprezentacje, Kraków 2018.

Sontag S., Choroba jako metafora. AIDS i jego metafory, przeł. J. Anders, Kraków 2016.

Sznajderman M., Zaraza. Mitologia dżumy, cholery i AIDS, Warszawa 1994.

Szubert M., Dyskurs maladyczny - perspektywy badawcze [w:] Fragmenty dyskursu maladycznego, red. M. Ganczar, I. Gielata, M. Ładoń, Gdańsk 2019, s. 17-35.

Świerkosz M., Atena i Arachne? Maria Dąrowska i Anna Kowalska we wzajemnej lekturze dzienników [w:] Czytanie. Kobieta, biblioteka, lektura, red. A. Zawiszewska, A. Galant, Szczecin 2015, s. 331-347.

19 J. Pilch, Drugi dziennik, Kraków 2014. Cyt. za: M. Ładoń, op.cit., s. 239. 